Georgia State University

ScholarWorks @ Georgia State University

\title{
Budget Transparency in Local Governments: An Empirical
} Analysis

Jose Caamano-Alegre

University of Santiago de Compostela, jose.caamano@usc.es

Santiago Lago-Penas

University of Vigo, slagop@uvigo.es

Francisco Reyes-Santias

University of Vigo, francisco.reyes@usc.es

Aurora Santiago-Boubeta

Municipality of Pontevedra, asantiago@pontevedra.eu

Follow this and additional works at: https://scholarworks.gsu.edu/icepp

Part of the Economics Commons

\section{Recommended Citation}

Caamano-Alegre, Jose; Lago-Penas, Santiago; Reyes-Santias, Francisco; and Santiago-Boubeta, Aurora, "Budget Transparency in Local Governments: An Empirical Analysis" (2011). ICEPP Working Papers. 83.

https://scholarworks.gsu.edu/icepp/83

This Working Paper is brought to you for free and open access by the International Center for Public Policy at ScholarWorks @ Georgia State University. It has been accepted for inclusion in ICEPP Working Papers by an authorized administrator of ScholarWorks @ Georgia State University. For more information, please contact scholarworks@gsu.edu. 


\section{International Studies Program}

Working Paper 11-02

February 2011

\section{Budget Transparency in Local} Governments: An Empirical Analysis

José Caamaño-Alegre

Santiago Lago-Peñas

Francisco Reyes-Santias

Aurora Santiago-Boubeta 



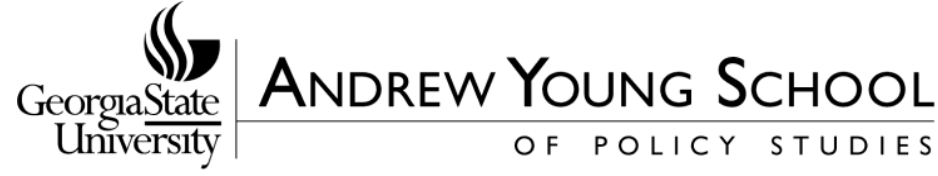

\author{
International Studies Program \\ Working Paper 11-02
}

\section{Budget Transparency in Local Governments: An Empirical Analysis}

\author{
José Caamaño-Alegre \\ Santiago Lago-Peñas \\ Francisco Reyes-Santias \\ Aurora Santiago-Boubeta
}

February 2011

International Studies Program

Andrew Young School of Policy Studies

Georgia State University

Atlanta, Georgia 30303

United States of America

Phone: (404) 651-1144

Fax: (404) 651-4449

Email: ispaysps@gsu.edu

Internet: http://isp-aysps.gsu.edu

Copyright 2006, the Andrew Young School of Policy Studies, Georgia State University. No part of the material protected by this copyright notice may be reproduced or utilized in any form or by any means without prior written permission from the copyright owner. 


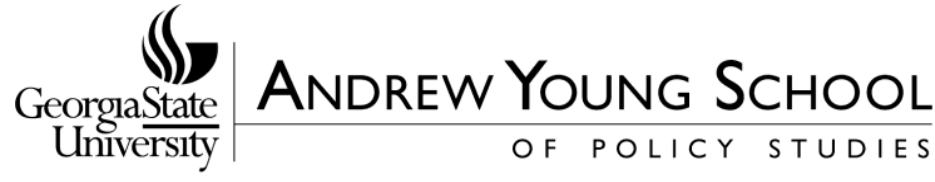

\section{International Studies Program Andrew Young School of Policy Studies}

The Andrew Young School of Policy Studies was established at Georgia State University with the objective of promoting excellence in the design, implementation, and evaluation of public policy. In addition to two academic departments (economics and public administration), the Andrew Young School houses seven leading research centers and policy programs, including the International Studies Program.

The mission of the International Studies Program is to provide academic and professional training, applied research, and technical assistance in support of sound public policy and sustainable economic growth in developing and transitional economies.

The International Studies Program at the Andrew Young School of Policy Studies is recognized worldwide for its efforts in support of economic and public policy reforms through technical assistance and training around the world. This reputation has been built serving a diverse client base, including the World Bank, the U.S. Agency for International Development (USAID), the United Nations Development Programme (UNDP), finance ministries, government organizations, legislative bodies and private sector institutions.

The success of the International Studies Program reflects the breadth and depth of the in-house technical expertise that the International Studies Program can draw upon. The Andrew Young School's faculty are leading experts in economics and public policy and have authored books, published in major academic and technical journals, and have extensive experience in designing and implementing technical assistance and training programs. Andrew Young School faculty have been active in policy reform in over 40countries around the world. Our technical assistance strategy is not to merely provide technical prescriptions for policy reform, but to engage in a collaborative effort with the host government and donor agency to identify and analyze the issues at hand, arrive at policy solutions and implement reforms.

The International Studies Program specializes in four broad policy areas:

- Fiscal policy, including tax reforms, public expenditure reviews, tax administration reform

- Fiscal decentralization, including fiscal decentralization reforms, design of intergovernmental transfer systems, urban government finance

- Budgeting and fiscal management, including local government budgeting, performancebased budgeting, capital budgeting, multi-year budgeting

- Economic analysis and revenue forecasting, including micro-simulation, time series forecasting,

For more information about our technical assistance activities and training programs, please visit our website at http://isp-aysps.gsu.edu or contact us by email at ispaysps@gsu.edu. 


\title{
Budget Transparency in Local Governments: An Empirical Analysis ${ }^{1}$
}

\author{
José Caamaño-Alegre*, Santiago Lago-Peñas**, Francisco Reyes-Santias***, \\ Aurora Santiago-Boubeta**** \\ *University of Santiago de Compostela \\ **REDE, IEB and University of Vigo \\ ***University of Vigo \\ ****Municipality of Pontevedra
}

\begin{abstract}
The aim of this paper is to shed additional light on the determinants of budget transparency in local governments. Our work is based on a Likert-type survey questionnaire specifically designed to measure budget transparency in small municipalities. The questionnaire is based on the IMF's revised Code of Good Practices on Fiscal Transparency (2007). Results from 33 Galician municipalities are used to assess its internal consistency and to test a battery of hypotheses on the determinants of budget transparency. While several previous findings of the literature are confirmed, some new results are also obtained.
\end{abstract}

Key words: budget transparency, local public finance, municipal budgeting, government accounting

JEL classification: $\mathrm{H} 72, \mathrm{H} 83, \mathrm{D} 73, \mathrm{D} 78$

*Contact email: jose.caamano@usc.es

** Contact email: http://webs.uvigo.es/slagop

*** Contact email: francisco.reyes@usc.es

**** Contact email: asantiago@pontevedra.eu 


\section{Introduction}

Despite a recent upsurge in popularity, concerns regarding budget transparency have a long tradition. The establishment of representative democracies throughout the Western world brought with it a resistance to the secrecy that had previously been the norm in governmental accounting. At the time, budget transparency was closely linked to notions of executive accountability and principles of clarity in budgeting.

However, in recent decades the term has been widely adopted by policy makers and popular media, and its meaning has evolved. Budget transparency is not just an element of governmental accountability to Parliament, but rather a tool for facilitating a relationship between public budgeting and market requirements, civil society demands and citizen participation.

Budget transparency is particularly important in local government. Globalization has given rise to a greater recognition of the role of local government, demonstrated by a widespread resort to the subsidiary principle and a growing municipal participation in public policies. The strengthening of local governments along with substantial changes in the way those governments operate has kindled the interest of stakeholders in knowing what governments do, how and at what price. Fairly often, international organizations involved in promoting budget transparency consider local governments to be ideal for testing new systems or arrangements before they are implemented at higher levels.

However, available empirical research on budget transparency tends to focus on national or regional governments. Moreover, studies generally rely on a few crude indicators or survey data from dichotomous-item questionnaires, often extracted from instruments designed for other purposes. Aimed at filling this gap, this paper presents a Likert-type survey questionnaire to measure budget transparency in municipalities. The use of a Likert scale ${ }^{1}$ promotes content validity ${ }^{2}$ and discreteness with a limited number of survey items. Rather than focusing on the existence of formal safeguards as evidence

\footnotetext{
${ }^{1}$ In this article, the word "scale" usually refers to "an instrument made up of multiple items that have a relationship to each other as well as to the concept of interest [budget transparency, in our case]" (Colton and Covert 2007: 249). A Likert scale is a scale composed of Likert-type items, as we explain in subsection 3.1. Although there are precedents for using Likert-type items in measuring budget transparency at the national level (Lavielle, Pérez and Hofbauer 2003; Pérez 2005), leading studies on determinants of budget transparency have tended to rely on the above-mentioned kinds of data.

${ }^{2}$ According to Colton and Covert (2007: 68), content validity is the degree to which an instrument is representative of the topic and process being investigated.
} 
of budget transparency, Likert scales make it possible to analyze the degree to which municipal practices and/or behaviors satisfy certain transparency-related criteria. Based on the answers to this survey by financial comptrollers from 33 Galician municipalities, we perform an empirical analysis on the determinants of transparency.

The paper is organized as follows: section 2 presents the definition, scope, and international standards for budget transparency. Relevant empirical studies on the determinants of budget transparency are also reviewed. Section 3 presents our survey and evaluates its consistency. Both the descriptive analysis and econometrics are contained in section three. Section 4 concludes.

\section{Approach to Budget Transparency: Definition, Scope, and Determinants.}

The notion of transparency is far from clear. According to Hood (2006: 3), "like many other notions of a quasi-religious nature, transparency is more often preached than practised, more often invoked than defined, and indeed might ironically be said to be mystic in essence, at least to some extent". As a general governmental requirement, transparency goes beyond mere access to information, demanding that information prove understandable to external stakeholders. However, the editors' note of the OECD Best Practices for Budget Transparency does not state this requirement specifically when it defines transparency as "openness about policy intentions, formulation and implementation", and budget transparency as "the full disclosure of all relevant fiscal information in a timely and systematic manner" (OECD 2001: 7). The OECD requires preparation of budget reports, disclosure of specific data, and the establishment of procedures to ensure integrity (Table 1).

Table 1: The "three pillars" of the OECD Best Practices for Budget Transparency

\begin{tabular}{lll}
\hline Budget Reports & Specific Disclosures & Ensuring Integrity \\
\hline - The Budget & $\bullet$ Economic Assumptions & - Accounting Policies \\
- Pre-Budget Report & - Tax Expenditures & - Systems and Responsibilities \\
- Monthly Report & - Financial Liabilities \& Assets & - Audit \\
- Mid-Year Report & - Non-Financial Assets & - Parliamentary and Public \\
- Year-End Report & • Employee Pension Obligations & Scrutiny \\
- Pre-Election Report & $\bullet$ Contingent Liabilities & \\
- Long-Term Report & & \\
\hline
\end{tabular}

Source: Blöndal (2006: 4-7). 
Although exposing the detailed development of the three pillars would be cumbersome, there are certain key elements which deserve to be highlighted. Regarding the budget reports, the OECD Best Practices outlines both minimum content and specific times when budget reports must be issued. Some prescriptions are based on classical principles such as universality or gross budgeting. Others, instead, are built upon more modern requirements that are still neglected in many countries, particularly in local governments ${ }^{3}$. A similar disparity is observed in the specific disclosures that form the second pillar and standard governmental practices. Few local governments in the world disclose the sensitivity analyses as required in standards 2.1 and 2.3 in fine, to show the effects of changes in macroeconomic variables like interest or exchange rates on budgeting. Concerning the integrity, control and accountability standards of the third pillar, a year-end report's audit by the Supreme Audit Institution is more common. Conversely, other arrangements like adjusting information on previous periods to provide temporal comparability, or making all reports available on line, seem to remain challenging for many local governments.

Recently, revised versions of the Code and the Manual on fiscal transparency of the International Monetary Fund were issued (IMF 2007a, 2007b). Built upon Kopits and Craig's (1998) definition of fiscal transparency, the code sets standards relative to the openness to the public about the structure and functions of government, fiscal policy intentions, public sector accounts, and fiscal projections. The IMF Code is structured around four pillars: (i) clarity of roles and responsibilities, (ii) open budget processes, (iii) public availability of information, and (iv) assurance of integrity. The first of these pillars can be considered beyond the scope of the OECD Best Practices, since that pillar focuses on the establishment of a clear distinction between public corporations, the private sector and the government. This is not the case with the last three pillars, which maintain multiple similarities with the OECD Best Practices, but go further in several respects ${ }^{4}$. We will thus limit the scope of budget transparency to the standards outlined

\footnotetext{
${ }^{3}$ For instance: $i$ ) inclusion of comparative and non-financial information, $i$ ) explanation of deviations, iii) consistency in format between the budget and the final report, iv) issuing of monthly reports within four weeks, and $v$ ) audit and issuing of the year-end report within of six months.

4 The second pillar also requires "clear mechanisms for the coordination and management of budgetary and extra-budgetary activities within the overall fiscal policy framework". The third and fourth pillars incorporate innovative provisions such as:

i) publication of a periodic report on long-term public finances;

ii) openness in purchase and sale of public assets;

iii) mechanisms to monitor follow-up actions recommended by the national auditor;
} 
in the last three pillars of the IMF Code, viewed as an updated and less detailed version of the OECD Best Practices.

Transparency in public financial management is also receiving increased attention in public administration, political science and economics research. Empirical research focuses primarily on testing the benefits of fiscal transparency. This is the case of the work by Alt and Lassen (2006) focused on the effects of fiscal transparency on the accumulation of public debt in OECD countries. When dealing with endogeneity problems of transparency as regressor, they also find that measures of political competition, presidential system and common law variables do well in explaining variation in transparency, whereas debt level has no statistically significant effect ${ }^{5}$.

A more direct analysis of transparency determinants is presented in Alt, Lassen and Rose (2006). Based on work by Hanssen (2004), the authors hypothesize that budgeting practices will be more transparent in systems marked by high political competition. In situations of high political turnover, incumbents will try to tie the hands of their potential successors (partisan adversaries) by reinforcing arrangements for transparency. In a similar vein, political polarization increases transparency; however, a more polarized polity could impede a cohesive reform policy and thus, become a hindrance to transparency. To these political but nonpartisan explanations, a partisan hypothesis is added that Democratic incumbents are more prone than Republicans to increase transparency, because of the greater transparency required for directing additional resources toward expand the public sector ${ }^{6}$. Along with political variables, the authors also note that financial outcomes may positively or negatively impact transparency. Incumbents may restrict access to information in order to avoid blame for poor fiscal performance, or facilitate information access to get credit for a favourable fiscal record. To test these theories, the authors construct an annual transparency score for the years between 1972-2002 using questionnaire data from budget officers in all 50 U.S. states. The authors then construct the following equation for estimating fiscal transparency:

iv) assessment of the fiscal forecasts, the macroeconomic forecasts, and their underlying assumptions by independent experts; and

v) institutional independence of the national statistical body.

5 See also Jarmuzek (2006). Although he does not detail the effects of his instrumental variables on fiscal transparency, the variables used in the model include a political competition index (i.e. past turnover), the rule of law, and the media freedom index compiled by the Freedom House.

${ }^{6}$ The authors base this hypothesis on model implications from Ferejohn's (1999). 


$$
y_{s t}=\alpha_{s t}+\gamma_{t}+\chi p_{s t}+\beta^{\prime} x_{s t}+v_{s t}
$$

where $y_{s t}$ represents the level of fiscal transparency in state $s$ in year $t, \alpha_{s}$ is a state fixed effect, $\gamma_{t}$ is a year indicator variable, $p_{s t}$ is the measure of political competition, $x_{\mathrm{st}}$ represents other political and economic variables, and $v_{s t}$ is the error term. The $x_{s t}$ term includes key fiscal variables such as deficit, debt, and revenue (all measured in real per capita terms). The term also includes socioeconomic controls such as real per capita income, income squared, population size, population squared, percent elderly, and percent school-aged. To allow for the fact that institutional changes occur, a series of lags for the independent variables are included and the lagged dependent variable is included as regressor.

The authors find that political competition tends to increase the level of fiscal transparency, whereas polarization appears as positively or negatively related to transparency depending on the regression specifications. A Democratic legislature is positively associated with transparency when controlling for the effects of debt, fiscal imbalance, and polarization; the same occurs when using an Arellano-Bond firstdifference GMM estimation of the main equations rather than fixed effects. Higher levels of debt are associated with lower transparency, while fiscal imbalance (in the form of higher surpluses or deficits) appears to contribute to greater transparency. According the authors, this "conjunction of debt and deficit results suggest that a deficit motivates reform more where the stock of debt is lower, that is, where the deficit more resembles a surprise or "crisis"' (Alt, Lassen and Rose 2006: 47).

Esteller-Moré and Polo-Otero (2008) combine political competition variables with tax pressure (proxied by the property tax rate) to explain fiscal transparency using data from Catalonian municipalities. The study also includes electoral participation, population size, and percent elderly as control variables. The resultant fiscal transparency indicator is a measure of municipal accountability, specifically, the timely submission of the following nine documents to the region's Supreme Auditing Institution: i) opening budget, ii) budget liquidation, iii) budgetary results, $i v$ ) closed years' budget liquidation, $v$ ) cash flow statement, $v i$ ) cash flow remainder, vii) balance sheet, viii) result statement, and $i x$ ) debt statement. Unfortunately, this indicator does not account for the accuracy of the documents, and tends to behave almost as a dichotomous variable, given that the most of municipalities confront the submission of 
such documents as an all-or-nothing decision. Nevertheless, the indicator is objective and available for a series of consecutive years and for a substantial number of municipalities. Logistic model estimation results confirm that electoral competition has a positive impact on fiscal transparency, whereas per capita debt has a negative impact. Among the control variables, electoral participation promotes fiscal transparency, while population negatively affects transparency, but only for the large municipalities (defined as those with more than 5,000 inhabitants).

\section{Empirical Analysis}

\subsection{Questionnaire design and Municipal Governments Surveyed}

To measure budget transparency in Galician municipalities, we designed a survey questionnaire composed of fifteen items based on the second, third and fourth pillars of the IMF's revised Code of Good Practices on Fiscal Transparency (2007). Items one through five correspond to the second pillar (open budget processes), items six through ten to the third (public availability of information), and items eleven through fifteen to the fourth pillar (assurances of integrity). As indicated above, adherence to the standards outlined in the first pillar of the IMF Code was not measured given that its content was not covered by the OECD Best Practices for Budget Transparency, used here as a reference to define the scope of budget transparency. Moreover, the most of the contents of the first pillar are beyond the municipalities' control. Definition of roles and competences along with a legal framework for public management are determined by basic national legislation, and are not applied at municipalities' discretion. 
Table 2: Survey questionnaire on municipal budget transparency

\section{QUESTIONNAIRE FOR DATA GATHERING (SURVEY ON MUNICIPAL BUDGET TRANSPARENCY)}

MUNICIPAL GOVERNMENT:

GOVERNMENT OFFICIAL (position of the surveyed):

\section{INSTRUCTIONS:}

Please indicate your level of agreement with the following statements as they pertain to your municipality: 5 indicates strong agreement, 4 agreement, 3 neither agree nor disagree, 2 disagreement and 1 strong disagreement.

1) The budget is made in accordance with the established timeline (with no or rare continuing appropriations) and documentation is submitted to the opposition parties early enough for their analysis (i.e. earlier than scheduled budget meetings).

2) Budget estimates and underlying economic assumptions are accurate and realistic.

3) Over the fiscal year, periodic information on budget execution is submitted on time to the entire Assembly (art. 207 TRLHL).

Full

disagree

4) Budget liquidation and general account are presented on time and incorporate the elements necessary to critically evaluate management (justification of budgetary changes, interannual comparison, explanation of the primary deviations...)...........................

5) Budget liquidation is subject to public debate in the Assembly

6) Financial accounting accurately reflects the patrimonial situation (amortizations, consistency principle, inventory, non-accounted invoices)

7) Arrears and non-accounted invoices do not significantly distort budget liquidation.

8) Spending programs are submitted to an efficiency analysis (costbenefit, cost-utility...) and, in the case of investments, to a study of their effects on running costs.

9) Citizens participate, to some extent, in creating a spending budget (it would comprise of the public consultation procedure and other ways in which a transparent participation is assured)

10) Budgetary information is available and easily accessible on- and offline for consultation by citizens.

11) In local public employment, conditions for access and promotion are established and fulfilled in such a way as to ensure transparency and equal opportunity

12) Actual observance of the public procurement regulations guarantees the integrity, transparency, impartiality and competition in this municipal management area.

13) Budgeted grants are almost always awarded by competitive merit based review....

14) At least a $70 \%$ of the budgetary expenditures are submitted for preaudit.

15) External auditing bodies receive timely documentation of the municipality's financial management, and issue reports, from which the municipality takes corrective action (in this case, "documentation" refers to budget liquidation, general account, lists of contracts and inter-governmental agreements, list of agreements to regularise irregular expenditures, etc.).

\begin{tabular}{|c|c|c|c|}
\hline 1 & 2 & 3 & 4 \\
\hline 1 & 2 & 3 & 4 \\
\hline 1 & 2 & 3 & 4 \\
\hline 1 & 2 & 3 & 4 \\
\hline 1 & 2 & 3 & 4 \\
\hline 1 & 2 & 3 & 4 \\
\hline 1 & 2 & 3 & 4 \\
\hline 1 & 2 & 3 & 4 \\
\hline 1 & 2 & 3 & 4 \\
\hline 1 & 2 & 3 & 4 \\
\hline 1 & 2 & 3 & 4 \\
\hline 1 & 2 & 3 & 4 \\
\hline 1 & 2 & 3 & 4 \\
\hline 1 & 2 & 3 & 4 \\
\hline
\end{tabular}

$\begin{array}{lllll}1 & 2 & 3 & 4 & 5\end{array}$


The questionnaire items are not only based on the IMF Code but on our own practical knowledge about budgetary processes at the local level of government. In particular, we tried to construct items to go beyond nominal fiscal transparency to measure effective transparency, as well (Heald 2003, 2006). The item selection was aimed at covering all the areas of budget content and budgetary process, but avoiding redundancy. To start, we constructed a list of 50 items which touched on the three pillars of interest within the IMF Code. In a second step, the number of items reduced to 15 in order that the questionnaire not be perceived as too time-consuming. The questions were based on a Likert (1932) scale, i.e., a summative scale consisting of Likert-type items. These items are designed as statements with which the respondents express their agreement or disagreement. We use numbers from 1 to 5 instead of the common wording: strongly disagree, disagree, no opinion, agree, and strongly agree.

The survey questionnaire was sent to 40 Galician municipalities. Responses from 35 were received, but two had to be discarded due to various shortcomings. The 33 municipalities included in the final sample are listed by alphabetical order in Table 3. The population is over 50,000 in three municipalities (13,24, and 28), between 20,001 and 50,000 in eight municipalities $(1,3,10,14,23,25,27$, and 33), between 10,001 and 20,000 in twelve $(2,5,6,9,15,17,18,22,29,30,31$, and 32), between 5,001 and 10,000 in seven $(7,12,16,19,20,21$, and 26) and below 5,000 in the remaining three municipalities (4, 8, and 11). In all cases, the survey was answered by the public officials responsible for pre-auditing transactions and/or accounting. Those officials were selected by means of a national competitive examination, and they have a deep knowledge of financial and fiscal laws as well as the budgetary reality of their municipalities. 
Table 3: Municipalities included in the sample

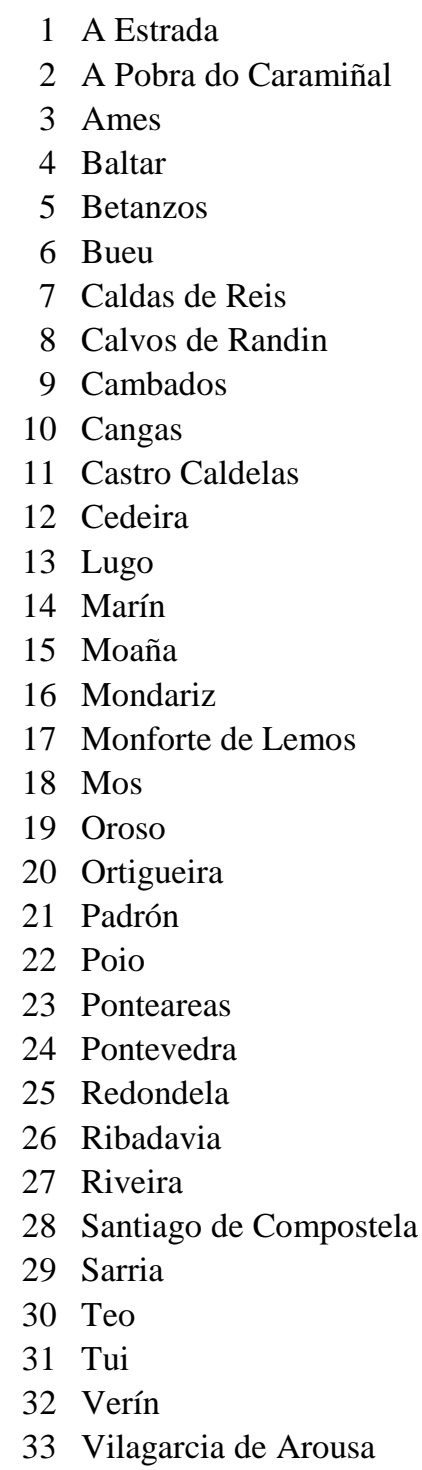

\subsection{Dimensionality and internal consistency issues}

The most common approach to the analysis of internal consistency of a social research instrument is an item analysis which considers both item-total correlation and inter-correlation among the items (Colton and Covert 2007: 72, 265-267). Item analyses and Cronbach's (1951) alpha coefficients are optimal tools for the assessment of internal consistency in a unidimensional scale with items measuring different substantive areas within a single concept.

Thus, in order to determine whether ITA is optimal, we should begin by using one of the many factor-analytic techniques currently available to make sure that there are no large departures from unidimensionality (Cortina 1993: 103). Taking into 
account the low number of observations, several principal component analysis tests confirmed that the instrument effectively was mainly unidimensional ${ }^{7}$.

In a second step, we evaluate internal consistency by examining inter-item correlations, item-total correlations and Cronbach's alpha. This classical approach was used for the following reasons: $i$ ) it is easily computable in standard statistical packages; ii) it compensates for the limited sample size by providing a synthetic measure based on all correlation matrix elements; and iii) as multidimensionality would increase the underestimating bias of Cronbach's $\alpha$, a high $\alpha$ is a reliable indicator of internal consistency ${ }^{8}$.

Prior to inter-item correlation analysis, the Kolgomorov-Smirnov test on normality of data was performed. According to results, the hypothesis of normal distribution should not be rejected ( $p$-value<0.05). Thus, the relationships among items can be measured through a Pearson correlation coefficient ${ }^{9}$, as shown in Table 4.

\footnotetext{
${ }^{7}$ Plotting the magnitude of the successive eigenvalues and applying the Cattell's (1966) Scree test, a sharp drop in eigenvalues from component one is observed.

8 Within a hierarchical factor model framework, Zinbarg et al. (2005) demonstrates that $\alpha$ underestimates reliability in the first three of four theoretical scenarios: (1) unidimensional scales with unequal general factor loadings, (2) multidimensional scales with equal general factor loadings, and (3) multidimensional scales with unequal general factor loadings. Only in the fourth case, unidimensional scales with equal general factor loadings - i.e., essential tau equivalence-, is $\alpha$ as appropriate as $\omega$ to measure reliability. Vehkalahti, Puntanen and Tarkkonen (2006: 2) also use alpha's underestimating bias to justify the search for and proposal of a new estimator suggesting that this estimator, called Tarkkonen's rho, provides a better alternative for Cronbach's $\alpha$.

9 According Revelle (2010: 216), the correlations associated with an ordinal scale are not Pearson's but Spearman's . However, Garson (2008) explains that ordinality in Likert scales refers only to an ordinal relationship of values within a single item: Likert response values are ordinal within any given item but sets of Likert items are not necessarily ordinal with respect to each other, and they can be used to form indexes.
} 
Table 4. Correlation analysis by Pearson coefficient.

\begin{tabular}{|c|c|c|c|c|c|c|c|c|c|c|c|c|c|c|c|}
\hline & & ITEM 1 & ITEM 2 & ITEM 3 & ITEM 4 & ITEM 5 & ITEM 6 & ITEM 7 & ITEM 8 & ITEM 9 & $\begin{array}{l}\text { ITEM } \\
10 \\
\end{array}$ & $\begin{array}{l}\text { ITEM } \\
11 \\
\end{array}$ & $\begin{array}{l}\text { ITEM } \\
12 \\
\end{array}$ & $\begin{array}{l}\text { ITEM } \\
13 \\
\end{array}$ & $\begin{array}{l}\text { ITEM } \\
14\end{array}$ \\
\hline \multirow[t]{2}{*}{$\begin{array}{l}\text { ITEM } \\
2 \\
\end{array}$} & $\begin{array}{l}\text { Pearson } \\
\text { Correlation }\end{array}$ & 0,39 & & & & & & & & & & & & & \\
\hline & $\begin{array}{l}\text { Sig. (2- } \\
\text { tailed) }\end{array}$ & 0,03 & & & & & & & & & & & & & \\
\hline \multirow[t]{2}{*}{$\begin{array}{l}\text { ITEM } \\
3 \\
\end{array}$} & $\begin{array}{l}\text { Pearson } \\
\text { Correlation }\end{array}$ & 0.28 & 0,31 & & & & & & & & & & & & \\
\hline & $\begin{array}{l}\text { Sig. (2- } \\
\text { tailed) }\end{array}$ & 0,11 & 0,08 & & & & & & & & & & & & \\
\hline \multirow[t]{2}{*}{$\begin{array}{l}\text { ITEM } \\
4 \\
\end{array}$} & $\begin{array}{l}\text { Pearson } \\
\text { Correlation } \\
\end{array}$ & 0,59 & 0,33 & 0,19 & & & & & & & & & & & \\
\hline & 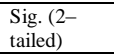 & 0,00 & 0,06 & 0,29 & & & & & & & & & & & \\
\hline \multirow[t]{2}{*}{$\begin{array}{l}\text { ITEM } \\
5 \\
\end{array}$} & $\begin{array}{l}\text { Pearson } \\
\text { Correlation }\end{array}$ & 0,31 & 0,06 & $-0,01$ & 0,31 & & & & & & & & & & \\
\hline & $\begin{array}{l}\text { Sig. (2- } \\
\text { tailed) }\end{array}$ & 0,08 & 0,75 & 0,97 & 0,08 & & & & & & & & & & \\
\hline \multirow[t]{2}{*}{$\begin{array}{l}\text { ITEM } \\
6 \\
\end{array}$} & $\begin{array}{l}\text { Pearson } \\
\text { Correlation } \\
\end{array}$ & 0,35 & 0,09 & 0,04 & 0,37 & 0,39 & & & & & & & & & \\
\hline & $\begin{array}{l}\text { Sig. (2- } \\
\text { tailed) }\end{array}$ & 0,05 & 0,62 & 0,82 & 0,03 & 0,03 & & & & & & & & & \\
\hline \multirow{3}{*}{$\begin{array}{l}\text { ITEM } \\
7 \\
\end{array}$} & $\begin{array}{l}\text { Pearson } \\
\end{array}$ & & & & & & & & & & & & & & \\
\hline & $\frac{\text { Correlation }}{\text { Sig. (2- }}$ & 0,36 & 0,46 & 0,35 & 0,47 & 0,27 & 0,44 & & & & & & & & \\
\hline & $\begin{array}{l}\text { triled) } \\
\text { taist }\end{array}$ & 0,04 & 0,01 & 0,05 & 0,01 & 0,13 & 0,01 & & & & & & & & \\
\hline \multirow{2}{*}{$\begin{array}{l}\text { ITEM } \\
8 \\
\end{array}$} & $\begin{array}{l}\text { Pearson } \\
\text { Correlation }\end{array}$ & 0,01 & 0,09 & 0,37 & 0,15 & $-0,0$ & 0,12 & $-0,03$ & & & & & & & \\
\hline & $\begin{array}{l}\text { Sig. (2- } \\
\text { tailed) }\end{array}$ & 0,97 & 0,61 & 0,03 & 0,41 & 0,65 & 0,50 & 0,89 & & & & & & & \\
\hline \multirow[t]{2}{*}{$\begin{array}{l}\text { ITEM } \\
9 \\
\end{array}$} & $\begin{array}{l}\text { Pearson } \\
\text { Correlation }\end{array}$ & 0,09 & 0,41 & 0,45 & $-0,10$ & 0,21 & 0,25 & 0,45 & 0,16 & & & & & & \\
\hline & $\begin{array}{l}\text { Sig. (2- } \\
\text { tailed) }\end{array}$ & 0,61 & 0,02 & 0,01 & 0,59 & 0,23 & 0,16 & 0,01 & 0,39 & & & & & & \\
\hline \multirow{3}{*}{$\begin{array}{l}\text { ITEM } \\
10\end{array}$} & $\begin{array}{l}\text { Pearson } \\
\text { Correlation }\end{array}$ & 00 & 077 & 037 & 019 & 006 & $0^{2}$ & 059 & 019 & 032 & & & & & \\
\hline & Sig. (2- & 0,02 & 0,27 & 0,31 & 0,19 & 0,00 & 0,21 & 0,59 & 0,19 & 0,22 & & & & & \\
\hline & tailed) & 0,92 & 0,13 & 0,03 & 0,29 & 0,72 & 0,24 & 0,00 & 0,29 & 0,07 & & & & & \\
\hline \multirow[t]{2}{*}{$\begin{array}{l}\text { ITEM } \\
11\end{array}$} & $\begin{array}{l}\text { Pearson } \\
\text { Correlation }\end{array}$ & 0,32 & 0,40 & 0,26 & 0,17 & 0,14 & 0,27 & 0,46 & $-0,19$ & 0,12 & 0,33 & & & & \\
\hline & $\begin{array}{l}\text { Sig. (2- } \\
\text { tailed) }\end{array}$ & 0,07 & 0,02 & 0,14 & 0,34 & 0,42 & 0,13 & 0,01 & 0,30 & 0,51 & 0,06 & & & & \\
\hline \multirow{3}{*}{$\begin{array}{l}\text { ITEM } \\
12 \\
\end{array}$} & Pearson & & & & & & & & & & & & & & \\
\hline & Correlation & 0,26 & 0,72 & 0,31 & 0,31 & 0,07 & 0,24 & 0,52 & 0,02 & 0,32 & 0,30 & 0,64 & & & \\
\hline & $\begin{array}{l}\text { Sig. (2- } \\
\text { tailed) }\end{array}$ & 0,15 & 0,00 & 0,08 & 0,07 & 0,70 & 0,18 & 0,00 & 0,93 & 0,07 & 0,09 & 0,00 & & & \\
\hline \multirow[t]{2}{*}{$\begin{array}{l}\text { ITEM } \\
13 \\
\end{array}$} & $\begin{array}{l}\text { Pearson } \\
\text { Correlation }\end{array}$ & 0,04 & 0,58 & 0,14 & 0,23 & 0,05 & 0,20 & 0,29 & $-0,03$ & 0,32 & 0,04 & 0,33 & 0,62 & & \\
\hline & $\begin{array}{l}\text { Sig. (2- } \\
\text { tailed) }\end{array}$ & 0,84 & 0,00 & 0,42 & 0,21 & 0,80 & 0,26 & 0,11 & 0,86 & 0,07 & 0,82 & 0,08 & 0,00 & & \\
\hline \multirow{3}{*}{$\begin{array}{l}\text { ITEM } \\
14\end{array}$} & Pearson & & & & & & & & & & & & & & \\
\hline & Correlation & 0,23 & 0,20 & $-0,02$ & 0,28 & 0,18 & 0,51 & 0,58 & $-0,08$ & 0,34 & 0,20 & 0,28 & 0,39 & 0,42 & \\
\hline & $\begin{array}{l}\begin{array}{l}\text { Sig. (2- } \\
\text { tailed) }\end{array} \\
\end{array}$ & 0,20 & 0,26 & 0,90 & 0,12 & 0,30 & 0,00 & 0,00 & 0,66 & 0,05 & 0,27 & 0,11 & 0,03 & 0,02 & \\
\hline \multirow[t]{2}{*}{$\begin{array}{l}\text { ITEM } \\
15 \\
\end{array}$} & $\begin{array}{l}\text { Pearson } \\
\text { Correlation }\end{array}$ & 0,73 & 0,41 & 0,44 & 0,68 & 0,27 & 0,45 & 0,49 & 0,28 & 0,17 & 0,15 & 0,32 & 0,41 & 0,14 & 0,26 \\
\hline & $\begin{array}{l}\text { Sig. (2- } \\
\text { tailed) }\end{array}$ & 0,00 & 0,02 & 0,01 & 0,00 & 0,12 & 0,01 & 0,00 & 0,12 & 0,35 & 0,40 & 0,07 & 0,02 & 0,44 & 0,1 \\
\hline
\end{tabular}

Source: Authors' calculations.

In order to obtain a global appraisal of internal consistency, mean inter-item correlation and an alpha coefficient for the total score were computed, with resulting values of 0.27 and 0.85 , respectively ${ }^{\mathbf{1 0}}$. This alpha clearly satisfies the widely held rule of thumb proposed by Nunnaly (1978), that an alpha of 0.7 or higher indicates internal

${ }^{10}$ When calculated from the correlation matrix (Table 4), a standardized alpha of 0.849 is obtained the same could be calculated from the covariance matrix by standardizing and summing all items in the scale. In our case, the raw alpha provided by SPSS $(0.850)$ is practically equal to the standardized alpha. In Table 5, raw alphas from SPSS are reported. 
consistency. Indeed, such $\alpha$ is within the ideal range between the consistency threshold (0.8) and the redundancy threshold $(0.9)^{\mathbf{1 1}}$.

The next step is to examine the consistency of each item with the scale as a whole, so we can identify any items which do not represent the latent variable being measured (budget transparency). The key results are in the last two columns of Table 5. The penultimate column indicates the correlation between each item and the average of the other items, while the last column reveals what the consistency of our scale would be if we would delete the given item (De Coster 2004: 47). If an item has a low correlation with total and its deletion causes a considerable increase in the alpha score, the item is suspected of inconsistency. In our case, items 8 and 5 are the least correlated with total and the only ones whose deletion causes an increase in $\alpha$. Although these increases are not considerable, the correlation of item 8 with the average of the other items is lower than the normal rule of thumb cited by Steiner and Norman (1995), of at least 0.20 . It suggests that item 8 is not reflecting only budget transparency but also financial management sophistication. Indeed, we expected a peculiar behavior in this item because most Galician municipalities have not yet developed a performance management approach, but other practical considerations led us to maintain the item.

\footnotetext{
${ }^{11}$ Although the widely-accepted social science criterion is that alpha should be 0.70 or higher for a set of items to be considered a scale, and even a lenient cut-off of 0.60 is common in exploratory research, many researchers require a score of 0.80 for a "good scale" (Garson 2008, 2010). On the other hand, a high alpha may also suggest a high level of item redundancy, wherein essentially the same item is rephrased in several different ways (Boyle 1991). Thus, for example, Fitzpatrick et al. (1998: 23) consider that alpha values should not be higher than 0.9 for scales which are used as research tools to compare groups. A very high $\alpha$ suggests that there is some redundancy among items, and the possibility that the items together are addressing a rather narrow aspect of an attribute.
} 
Table 5. Item-Total Statistics.

\begin{tabular}{|l|r|r|r|r|}
\hline & $\begin{array}{c}\text { Scale Mean if } \\
\text { Item Deleted }\end{array}$ & $\begin{array}{c}\text { Scale } \\
\text { Variance if } \\
\text { Item Deleted }\end{array}$ & $\begin{array}{c}\text { Corrected } \\
\text { Item-Total } \\
\text { Correlation }\end{array}$ & $\begin{array}{c}\text { Cronbach's } \\
\text { Alpha if Item } \\
\text { Deleted }\end{array}$ \\
\hline ITEM 1 & 36.45 & 83.506 & 0.510 & 0.840 \\
ITEM 2 & 35.70 & 84.405 & 0.591 & 0.836 \\
ITEM 3 & 36.79 & 86.610 & 0.414 & 0.845 \\
ITEM 4 & 35.70 & 83.593 & 0.535 & 0.838 \\
ITEM 5 & 35.76 & 87.439 & 0.285 & $\mathbf{0 . 8 5 6}$ \\
ITEM 6 & 36.52 & 86.445 & 0.505 & 0.840 \\
ITEM 7 & 35.76 & 77.939 & 0.745 & 0.824 \\
ITEM 8 & 37.27 & 95.080 & $\mathbf{0 . 1 0 9}$ & $\mathbf{0 . 8 5 6}$ \\
ITEM 9 & 36.82 & 87.466 & 0.434 & 0.844 \\
ITEM 10 & 36.21 & 87.610 & 0.399 & 0.846 \\
ITEM 11 & 35.73 & 85.267 & 0.490 & 0.841 \\
ITEM 12 & 35.55 & 83.568 & 0.652 & 0.833 \\
ITEM 13 & 35.91 & 87.710 & 0.408 & 0.845 \\
ITEM 14 & 35.18 & 84.903 & 0.478 & 0.842 \\
ITEM 15 & 36.00 & 82.500 & 0.670 & 0.831 \\
\hline
\end{tabular}

Finally, internal consistency of our three subscales was also evaluated by the alpha coefficient, obtaining the following values: Open Budget Processes (items 1 to 5), 0.649; Public Availability of Information (items 6 to 10), 0.674; and Assurances of Integrity (items 11 to 15$), 0.748$. While these values are lower than the total alpha for all 15 items together, they can be considered adequate for subscales with a limited number of items. Corrected item-total correlation and alpha if item deleted were also computed for each subscale, in order to examine the consistency of each item with the subscale as a whole. Again, item 8 is the only item whose correlation with the average of the remaining items of its subscale is lower than 0.2. This result is consistent with those of an additional PCA/FA on our subscales, according to which all of the second subscale's items besides item 8 loaded onto a single factor.

\subsection{Descriptive analysis of the survey results}

Respondents' mean scores by item show the distribution reflected in figure 1, with most of the municipalities clustered around the sample mean (2.5778). Insofar as this score is below 3, the average perception resulting from the survey is like a fail grade in budget transparency. Descriptive statistics by item are shown in Table 6. 


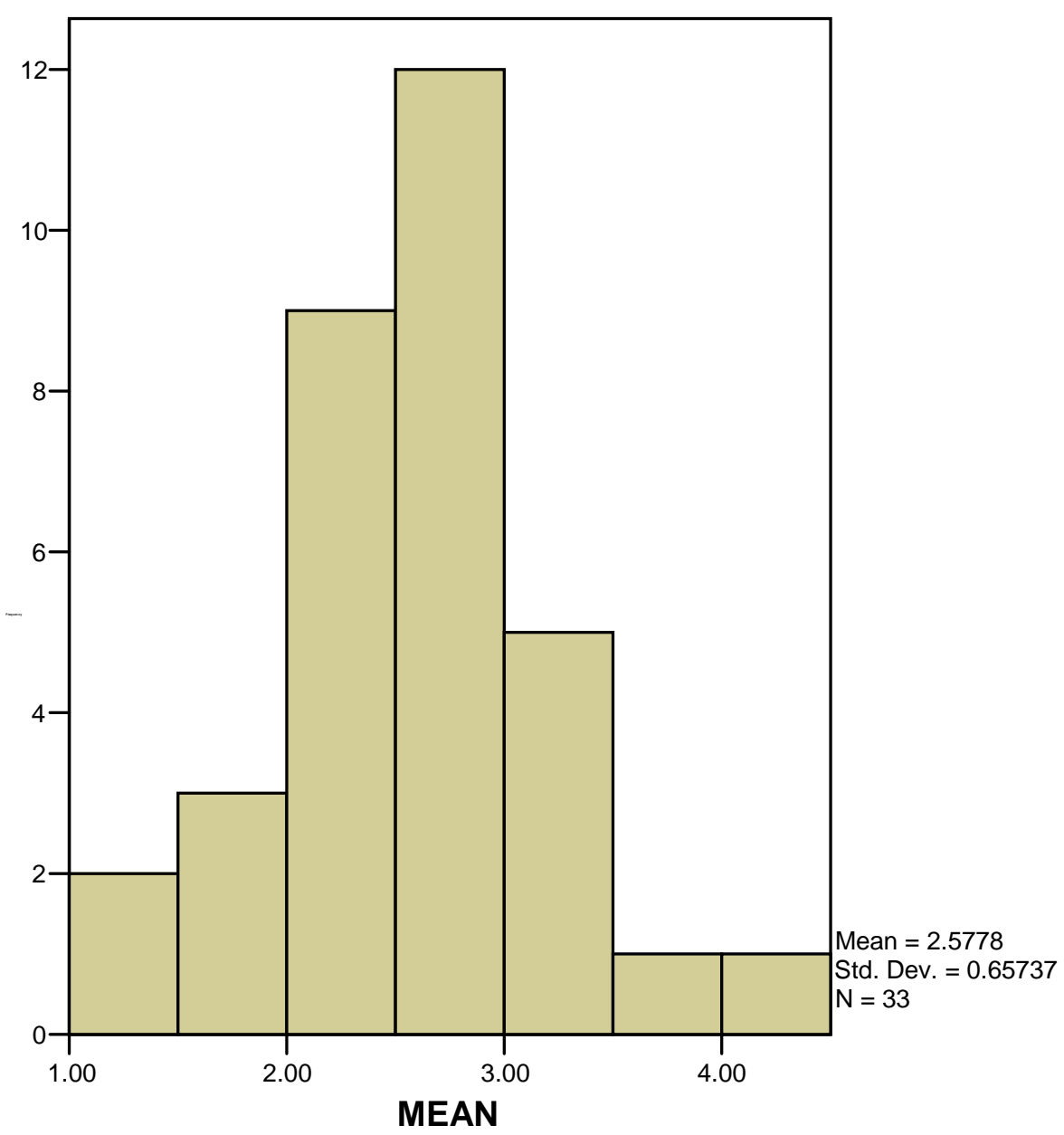

Table 6. Descriptive Statistics.

\begin{tabular}{|l|l|r|r|r|r|r|}
\hline & $\mathrm{N}$ & Minimum & Maximum & Sum & Mean & Std. Deviation \\
\hline ITEM 1 & 33 & 1 & 5 & 73 & 2.21 & 1.293 \\
ITEM 2 & 33 & 1 & 5 & 98 & 2.97 & 1.075 \\
ITEM 3 & 33 & 1 & 5 & 62 & 1.88 & 1.193 \\
ITEM 4 & 33 & 1 & 5 & 98 & 2.97 & 1.237 \\
ITEM 5 & 33 & 1 & 5 & 96 & 2.91 & 1.444 \\
ITEM 6 & 33 & 1 & 4 & 71 & 2.15 & 1.034 \\
ITEM 7 & 33 & 1 & 5 & 96 & 2.91 & 1.331 \\
ITEM 8 & 33 & 1 & 4 & 46 & 1.39 & 0.747 \\
ITEM 9 & 33 & 1 & 4 & 61 & 1.85 & 1.064 \\
ITEM 10 & 33 & 1 & 5 & 81 & 2.45 & 1.121 \\
ITEM 11 & 33 & 1 & 5 & 97 & 2.94 & 1.171 \\
ITEM 12 & 33 & 1 & 5 & 103 & 3.12 & 1.053 \\
ITEM 13 & 33 & 1 & 5 & 91 & 2.76 & 1.091 \\
ITEM 14 & 33 & 1 & 5 & 115 & 3.48 & 1.228 \\
ITEM 15 & 33 & 1 & 5 & 88 & 2.67 & 1.109 \\
\hline
\end{tabular}

Source: Authors' survey.

The elements perceived as more transparent are those covered by items 12 and 14. Both items are proxies for the observance of public procurement regulations and the 
pre-audit coverage. At the opposite extreme, the less transparent areas are those represented by items 8, 9, and 3: efficiency analysis prior to approval of spending programs, citizen participation in budget making, and periodic submission of spending information. This last result is easily understandable: while the Spanish Local Finances Act (TRLHL) requires access to information on budget execution, the definition is left up to each municipal government, leading to a nearly total negligence of this obligation.

Item 8 has the lowest standard deviation of any item (0.747), suggesting that municipalities rarely conduct efficiency analysis prior to the approval of spending programs. The mean item score is 1.39 , with a minimum possible score of 1 . The highest standard deviations are those for items 5 (1.444), 7 (1.331), and 1 (1.293), which suggests a certain heterogeneity among municipalities with regard to the budget liquidation, arrears and non-accounted invoices, timeliness of budget making and openness to the opposition.

Based on the survey results, a fiscal transparency index is constructed in order to rank the thirty-three municipalities with regards to transparency. The index is calculated by summing the scores recorded for all survey items. So,

$$
\text { General Transparency Index }=\sum X i
$$

where $X$ are the item scores, and $i$ varies from 1 to 15 .

From this straightforward calculation, we calculate an index score for each municipality, resulting in the following ranking table. 
Table 7. Municipal ranking table according to our Fiscal Transparency Index.

\begin{tabular}{|c|c|c|c|c|c|}
\hline Position & Municipality & $\begin{array}{l}\text { Index } \\
\text { Score }\end{array}$ & Position & Municipality & $\begin{array}{l}\text { Index } \\
\text { Score }\end{array}$ \\
\hline 1 & Lugo & 62 & 18 & Tui & 39 \\
\hline 2 & Monforte de Lemos & 56 & 19 & Oroso & 38 \\
\hline 3 & Rivadavia & 52 & 20 & Santiago de Compostela & 37 \\
\hline 4 & Ortigueira & 50 & 21 & Moaña & 36 \\
\hline 5 & A Estrada & 47 & 21 & Calvos de Randin & 36 \\
\hline 5 & Padrón & 47 & 23 & Redondela & 35 \\
\hline 5 & Riveira & 47 & 24 & Marín & 32 \\
\hline 8 & Pontevedra & 44 & 25 & Baltar & 31 \\
\hline 8 & Cedeira & 44 & 25 & Cambados & 31 \\
\hline 8 & Caldas de Reis & 44 & 25 & Cangas & 31 \\
\hline 11 & A Pobra do Caramiñal & 43 & 28 & Bueu & 30 \\
\hline 11 & Poio & 43 & 29 & Mos & 27 \\
\hline 13 & Castro Caldelas & 42 & 30 & Betanzos & 24 \\
\hline 13 & Sarria & 42 & 30 & Verín & 24 \\
\hline 13 & Teo & 42 & 32 & Mondariz & 21 \\
\hline 16 & Ames & 40 & 33 & Ponteareas & 19 \\
\hline 16 & Vilagarcia de Arousa & 40 & & & \\
\hline
\end{tabular}

Differences in scores among municipalities are significant, with the top-ranked municipality (Lugo) scoring 10\% higher than the second-ranked municipality (Monforte de Lemos) which, in turn, scores three times higher than the lowest ranked municipality (Ponteareas). It is equally remarkable that the municipalities ranked lowest for budget transparency are those in the worst economic situation (Santiago, Cambados, Cangas, Ponteareas, Betanzos), as determined by the Galician Supreme Audit Institution.

\subsection{Econometric analysis of the determinants of budget transparency}

\subsubsection{Econometric specification and data}

In order to disentangle the determinants of budget transparency in local governments, we have clustered explicative variables into three categories: socioeconomic factors, fiscal variables, and political factors. Preliminary analyses were run in order to test potential multicollinearity ${ }^{\mathbf{1 2}}$. All variables and data sources are defined in table 8. Two are socioeconomic variables (population size and unemployment rate), four are fiscal variables (per capita fiscal balance, expenditure

\footnotetext{
12 In particular, we detected a high correlation between aging, population size, municipal public expenditure over municipal GDP, and per capita GDP. Youth migrate from backward municipalities in terms of GDP, bringing about both the ageing and reduction of total population. Insofar as local expenditure is partially financed by equalization grants, the public expenditure/GDP ratio tends to be higher in the backward municipalities. Dropping per capita GDP and ageing from the specification substantially reduced multicollinearity among the independent variables.
} 
over municipal GDP, per capita debt, and tax pressure), and four represent political features (incumbent's ideology, effective number of political parties, coalition governments, and political participation). Table 9 reports descriptive statistics for both endogenous and exogenous variables.

Table 8: Definition of explicative variables and data sources

\begin{tabular}{|c|c|c|c|}
\hline CATEGORY & NAME & DEFINITION & DATA SOURCE \\
\hline Socio-economic & $P O P$ & Number of inhabitants expressed in thousands (2008) & www.ige.eu \\
\hline Socio-economic & $U$ & Unemployment rate expressed in percentage (annual average 2008) & www.ine.es \\
\hline Fiscal & $B A L$ & Municipal budget balance expressed in per capita euros (2006) & $\frac{\text { www.ccontasgalicia.es and }}{\text { www.ine.es }}$ \\
\hline Fiscal & $E$ & Municipal public expenditure over GDP expressed in percentage (2006) & $\begin{array}{l}\frac{\text { www.ccontasgalicia.es }}{\text { www.ine.es }} \\
\text { ww. }\end{array}$ \\
\hline Fiscal & $\bar{D}$ & Municipal public debt expressed in per capita euros (2006) & $\frac{\text { www.ccontasgalicia.es }}{\text { www.ine.es }}$ and \\
\hline Fiscal & $T$ & Municipal taxes expressed in per capita euros (2006) & $\frac{\text { www.ccontasgalicia.es }}{\text { www.ine.es }}$ \\
\hline Political & $P A R T$ & $\begin{array}{c}\text { Political participation in the last local election (2007) expressed in } \\
\text { percentage }\end{array}$ & http://www.mir.es/DGPI/ \\
\hline Political & COAL & $\begin{array}{l}\text { Dummy variable coded } 1 \text { in the case of coalition incumbents and } 0 \text { otherwise } \\
\text { (2008) }\end{array}$ & $\begin{array}{l}\text { Own authors from several } \\
\text { sources }\end{array}$ \\
\hline Political & LEFT & $\begin{array}{l}\text { Dummy variable coded } 1 \text { in the case of leftist incumbents and } 0 \text { otherwise } \\
\text { (2008) }\end{array}$ & $\begin{array}{l}\text { Own authors from several } \\
\text { sources }\end{array}$ \\
\hline Political & ENPP & $\begin{array}{l}\text { Effective number of political parties. According to Laakso and Taagapera } \\
\text { (1979) it is computed using tbe following formula: } N=\frac{1}{\sum_{i=1}^{n} p_{i}^{2}} \text {. Where } \\
\mathrm{n} \text { is the effective number of parties and } p_{i}^{2} \text { the square of each party's } \\
\text { proportion of all votes in } 2007 \text { municipal elections. }\end{array}$ & $\begin{array}{l}\text { Authors calculations with } \\
\text { data from } \\
\text { http://www.mir.es/DGPI/ }\end{array}$ \\
\hline
\end{tabular}


Table 9: Descriptive statistics of variables

\begin{tabular}{|c|c|c|}
\hline VARIABLE & MEAN & STANDARD DEVIATION \\
\hline$G T I$ & 38.7 & 9.86 \\
\hline$P T I_{1}$ & 12.9 & 4.05 \\
\hline $\mathrm{PTI}_{2}$ & 10.8 & 3.54 \\
\hline $\mathrm{PTI}_{3}$ & 15.0 & 3.99 \\
\hline$P O P$ & 21.9 & 23.6 \\
\hline $\bar{U}$ & 6.66 & 1.61 \\
\hline$B A L$ & 23.7 & 79.8 \\
\hline$E$ & 4.70 & 2.10 \\
\hline$D$ & 482.5 & 215.3 \\
\hline$T$ & 84.23 & 26.8 \\
\hline$P A R T$ & 66.26 & 5.69 \\
\hline$C O A L$ & 0.51 & DUMMY VARIABLE $(0 / 1)$ \\
\hline$L E F T$ & 0.66 & DUMMY VARIABLE $(0 / 1)$ \\
\hline$E N P P$ & 3.25 & 0.55 \\
\hline
\end{tabular}

The expected sign of the independent variables is the following:

- POP: The expected sign is positive. Larger administrative staffs in large municipalities make it easier to meet transparency requirements (Esteller and Polo 2008) ${ }^{\mathbf{1 3}}$.

- $U$ : The expected sign is negative: the worse the economic situation, the stronger the temptation to conceal fiscal stress ${ }^{14}$.

- BAL: The effect of this variable is ambiguous. As explained in section 2, the incumbents would hover between their desires to disengage from adverse fiscal results and to take credit for positive fiscal outcomes (Alt, Lassen and Rose $2006)^{15}$.

${ }^{13}$ Alt, Lassen and Rose (2006) find a non-significant effect. Esteller and Polo (2008) obtain a negative effect, but only for municipalities with over 5,000 inhabitants.

${ }^{14}$ LaFaive (2009) detects a negative relationship between unemployment and the transparency of a Michigan's program for economic development. However, Peixoto (2010) finds no correlation between the US states' levels of unemployment and the transparency of their recovery websites. Moreover, Andersen and Nielsen (2010: 28) suggest that the extremely damaging nature of procyclical fiscal policies during recessions may trigger reforms that increase the degree of fiscal transparency. Other studies on transparency also consider unemployment (Alt, Lassen and Skilling 2001; Rosendorff and Vreeland 2009), but not as a determinant of transparency.

${ }^{15}$ In the Alt, Lassen and Rose's (2006) empirical analysis, the resulting sign is positive for imbalance (both surplus and deficit), implying that the greater deficit spending leads to greater fiscal transparency. 
- E: Ambiguous. While a larger governmental budget may increase the demand for fiscal transparency and provide the administrative support necessary to meet transparency requirements (La Porte, Demchak and Jong 2002), a larger budget may also increase opportunities for corruption and rent-seeking (Alesina and Angeletos 2005) ${ }^{\mathbf{1 6}}$.

- $D$ : Ambiguous according to the same logic as $B A L$.

- $T$ : Positive. When the tax burden is higher, the taxpayers' demand for budget transparency is stronger ${ }^{17}$.

- PART: Positive. A higher voter turnout would indicate that citizens have a stronger interest in government activities (La Porte, Demchak and Jong 2002: 428; Esteller and Polo 2008) ${ }^{\mathbf{1 8}}$.

- COAL: Ambiguous. While Alt, Lassen and Rose (2006) argue that coalitions lead to greater transparency, Lago-Peñas and Lago-Peñas (2010) show that more political parties corresponds to less electoral control by incumbents.

- LEFT: Positive. Leftist incumbents are more likely to increase revenues to expand public services, and therefore face the greater transparency requirements from the public ${ }^{19}$.

\footnotetext{
${ }^{16}$ La Porte, Demchak and Jong (2002) fail to obtain empirical support for their hypothesized positive effect of government size on openness, although in some of their tests the "government size" variable does not remain after removing accounting for obvious collinearity. Bastida and Benito (2007: 690-691) observe that the relative size of central government presents a low significant $(p$-value $=0.079)$ negative relationship (-0.260) with budget transparency. According to the authors, although the study shows that larger central governments are linked to lower levels of transparency, the low significance prevents using the evidence to draw a strong conclusion.

17 Alt, Lassen and Rose (2006) find that per capita general revenues are not significant in most estimates. In Esteller and Polo (2008) taxes are only significant at $10 \%$ in a cluster model, with the expected positive sign.

18 Although La Porte, Demchak and Jong (2002) find no empirical support for the hypothesized impact of democracy on web site openness, they appear not include the "voting" variable in testing. Esteller and Polo (2008), however, confirm a positive relationship between electoral participation and fiscal transparency, and Rosendorff and Vreeland (2009) do the same for democracy and transparency. Finally, Bastida and Benito (2007: 690) find no significant correlations between their democratic-level variables and budget transparency, although they suggest that the direction of the relationships supports the notion that greater levels of political and civil liberty, correspond to higher fulfilment of the OECD Best Practices for Budget Transparency.

${ }^{19}$ As pointed out in the above mentioned section, Alt, Lassen and Rose's (2006) econometric analysis corroborates this positive relationship when controlling for the effects of debt, fiscal imbalance, and polarization, as well as when using an Arellano-Bond GMM first-difference estimation of their main equations. By contrast, Esteller and Polo (2008) find the variable is not significant, and Bastida and Benito (2007: 692) do not find any relationship between ideology and budget transparency.
} 
- ENPP: Positive. According to Alt, Lassen and Rose (2006), incumbents will be more likely to increase transparency when leaving office, in order to tie the hands of their successor.

Two basic econometric specifications were estimated. While specification [3] is used to analyze the determinants of the global transparency index $(G T I)$, specification [4] was constructed using information on the three partial indexes (PTI) corresponding to the subscales defined above. The list of explanatory variables is the same in both cases:

$$
\begin{aligned}
& \operatorname{GTI}_{i}=\alpha+\sum_{h=1}^{n} \beta_{h} \cdot X_{h i}+\sum_{h=1}^{m} \delta_{h} \cdot W_{h i}+\sum_{h=1}^{p} \gamma_{h} \cdot Z_{h i}+\varepsilon_{i} \\
& P T I_{j i}=\alpha_{j}+\sum_{h=1}^{n} \beta_{h j} \cdot X_{h j i}+\sum_{h=1}^{m} \delta_{h j} \cdot W_{h j i}+\sum_{h=1}^{p} \gamma_{h j} \cdot Z_{h j i}+\varepsilon_{j i} \quad(\text { with } j=1,2,3)
\end{aligned}
$$

In both expressions $X$ is the set of $n$ socioeconomic variables, $W$ is the set of $m$ fiscal variables, and $Z$ is the set of $p$ political factors. Subindex i refers to municipality ( $i$ $=1, . .33)$ and subindex $\mathrm{j}$ to the partial transparency index $(\mathrm{j}=1, \ldots 3)$. The decomposition of the general transparency index into three partial indexes $\left(G T I_{i}=\sum_{j=1}^{3} P T I_{j i}\right)$ allows us to triple the number of observations (from 33 to 99) and to check for the existence of different effects of regressors on the several areas of budget transparency. In the case of equation [3], we present results obtained with both the full list of regressors and after dropping irrelevant variables ${ }^{\mathbf{2 0}}$, in order to gain precision and degrees of freedom in estimates (Table 10). In the case of equation [4], only results obtained from this second step are reported (Table 11).

\subsubsection{Econometric methods and results}

Equations [3] and [4] are estimated using Ordinary Least Squares. Given that several tests (White, Breusch-Pagan-Godfrey, Cook-Weisberg) detected the presence of heteroskedasticity, standard errors are replaced by White robust errors in the case of

\footnotetext{
${ }^{20}$ Variables defined as those with a t-statistic below unity (in absolute value) in the first step: 4 variables in the case of equation [3] and up to 13 variables in the case of [4]. A Wald test on the joint significance of those variables clearly failed to reject the null hypothesis in both cases ( $\mathrm{p}$-values $=0.73$ and 0.42 , respectively)
} 
specification [3] and clustered errors by municipality in the case of specification [4]. Multicollinearity is not a serious concern according to the so-called "Klein's rule".

In both cases, the Ramsey's RESET test is computed ${ }^{\mathbf{2 1}}$. Specification errors may be discarded at usual significance levels in all cases. Goodness of fit significantly increases when moving form specification [3] $\left(\mathrm{R}^{2}=0.549\right)$ to specification [4] $\left(\mathrm{R}^{2}=0.959\right)$. Results are not reported. Normality of residuals was also confirmed performing the Jarque-Bera test.

We also tested the endogeneity of some of the right-hand variables using a graphical display of the cumulative sum (CUSUM) of the recursive residuals associated with a specific ordering of cross-sectional data (de Luna and Johansson 2008). In particular we tested the endogeneity of variables $B A L, E$ and $D$ ( $T$ is not relevant to the explanation of $G T I$ or $P T I_{j}$ ) by sorting the data with respect to those variables and looking at recursive residuals obtained from the estimates in column 1 of Table 10. Figures 2 to 4 display the CUSUM plots for $B A L, E$ and $D$ and show no evidence of endogeneity.

Figure 2: CUSUM plot. Data sorted with respect to variable $E$

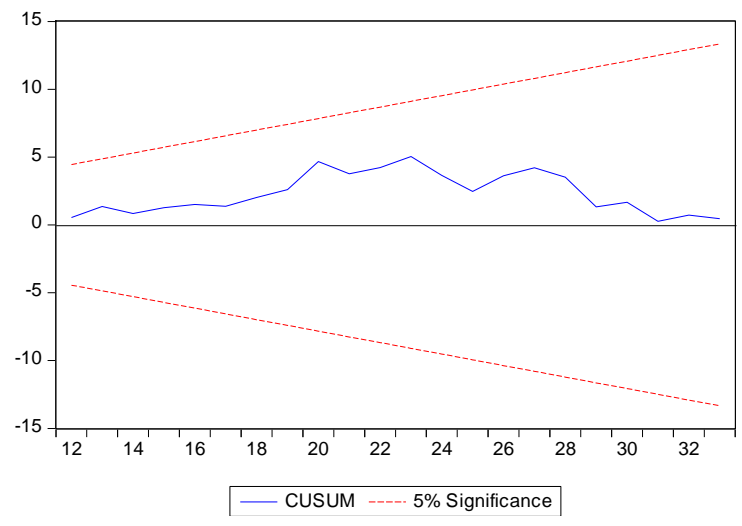

\footnotetext{
${ }^{21}$ RESET is a general test for the following types of specification errors: Omitted variables, incorrect functional form, and correlation between the exogenous variables and the random term which may be caused by measurement error or simultaneity, among other things.
} 
Figure 3: CUSUM plot. Data sorted with respect to variable $B A L$

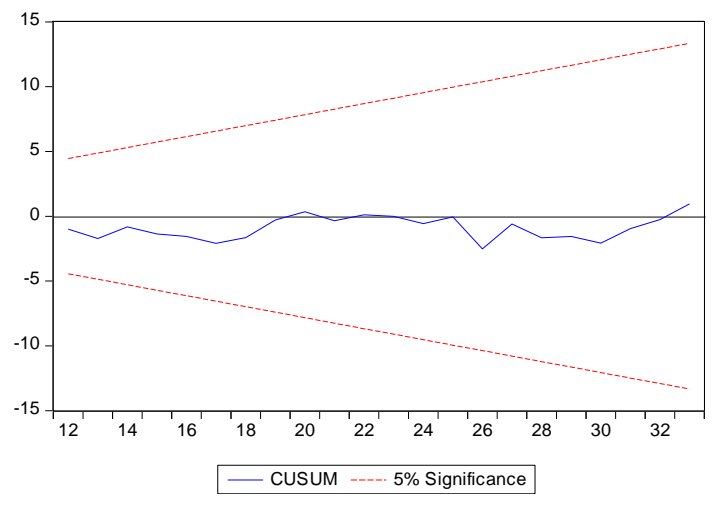

Figure 4: CUSUM plot. Data sorted with respect to variable $D$

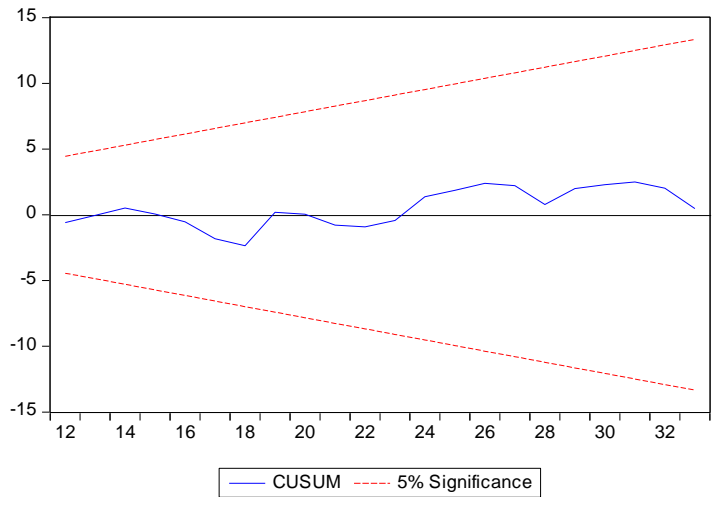

Finally, we checked the robustness of the results using the quasi-maximum likelihood estimator (QMLE) suggested by Papke and Woolridge (1996) to deal with constrained fractional response variables. By definition, variables GTI and PTI are constrained on the interval [15-75] and [5-25] respectively. However, OLS does not guarantee that the predicted values of the dependent variable lie on the unit interval. The QMLE do not suffer from this shortcoming. To facilitate the comparison between the OLS and the QMLE estimates, in the last column of Tables 10 and 11 the marginal effects of regressors in the sixth model are shown. Since the value of the marginal effect depends on the value of all variables in the model, they have been computed with all variables held constant at their mean values, except in the case of dummy variables, computed for discrete changes from 0 to 1. Results from OLS and QMLE are the same, with coefficients and z-statistics slightly higher in absolute value in the case of the latter.

In the case of the global transparency index, five regressors are significant at the $5 \%$ level $(U, B A L, C O A L, L E F T, E N P P)$ and one is significant at $10 \%(E)$. Variables 
$E N P P, L E F T$, and $B A L$ have a positive coefficient and $U, E$, and $C O A L$ show negative coefficients. Hence transparency is higher in the case of leftist incumbents and increases with electoral competition and better budget balance. Conversely, unemployment, coalition incumbents, and budget size in terms of municipal GDP reduce global transparency. These results deserve some comments. Our previous hypotheses regarding the unemployment impact on transparency are consistent with estimates obtained for both $U$ and $B A L$. The most surprising result is the negative sign on $C O A L$. It suggests a trade-off between the desires of tying the partner's hands (transparency) and escaping the vigilance of the partner (opacity), and is resolved in favor of the latter. This is understandable given that settling new control or transparency arrangements is more conflictive when controllers and controlees are in different parties; "turning a blind eye" is one way to reduce conflict to tolerable levels.

Table 10: Econometric estimates of equation [3]

\begin{tabular}{|c|c|c|c|c|}
\hline Independent variable & (1) & (2) & (3) & $\begin{array}{c}(4) \\
(d y / d x)\end{array}$ \\
\hline Intercept & $\begin{array}{l}28.11 \\
(1.03)\end{array}$ & $\begin{array}{c}37.09 * * * \\
(3,62)\end{array}$ & $\begin{array}{l}0.004 \\
(0.01)\end{array}$ & \\
\hline$P O P$ & $\begin{array}{c}0.07 \\
(0.73) \\
\end{array}$ & & & \\
\hline$U$ & $\begin{array}{c}-2.31 * * * \\
(3.04) \\
\end{array}$ & $\begin{array}{c}-2.11 \text { *** } \\
(2.75) \\
\end{array}$ & $\begin{array}{c}-0.12 * * * \\
(2.95) \\
\end{array}$ & -2.91 \\
\hline$B A L$ & $\begin{array}{c}0.04 * * * \\
(2.65)\end{array}$ & $\begin{array}{c}0.05^{* * * *} \\
(3.87) \\
\end{array}$ & $\begin{array}{c}0.003 * * * \\
(4.19)\end{array}$ & 0.06 \\
\hline$E$ & $\begin{array}{l}-0.98^{*} \\
(1.73) \\
\end{array}$ & $\begin{array}{l}-0.89 * \\
(1.78) \\
\end{array}$ & $\begin{array}{c}0.05^{*} \\
(1.89) \\
\end{array}$ & -1.20 \\
\hline$D$ & $\begin{array}{l}0.004 \\
(0.49) \\
\end{array}$ & & & \\
\hline$T$ & $\begin{array}{l}-0.025 \\
(0.29)\end{array}$ & & & \\
\hline$P A R T$ & $\begin{array}{c}0.13 \\
(0.54) \\
\end{array}$ & & & \\
\hline$C O A L$ & $\begin{array}{l}-5.59 * * \\
(2.15)\end{array}$ & $\begin{array}{c}-6.45^{* *} \\
(2.02)\end{array}$ & $\begin{array}{c}-0.35^{* *} \\
(2.15)\end{array}$ & -8.75 \\
\hline$L E F T$ & $\begin{array}{l}9.00 * * \\
(2.59)\end{array}$ & $\begin{array}{c}9.35 * * * \\
(3.31)\end{array}$ & $\begin{array}{c}0.50 * * * \\
(3.46)\end{array}$ & 12.46 \\
\hline$E N P P$ & $\begin{array}{c}5.11 \\
(1.48)\end{array}$ & $\begin{array}{l}4.83 * * \\
(2.34)\end{array}$ & $\begin{array}{c}0.260 * * * \\
(2.51)\end{array}$ & 6.51 \\
\hline $\mathrm{R}^{2}$ & 0.590 & 0.549 & & \\
\hline Log pseudo-likelihood & & & 33.62 & \\
\hline RESET (p-value) & 0.166 & 0.075 & & \\
\hline Number of observations & 33 & 33 & 33 & \\
\hline Econometric Method & Robust OLS & Robust OLS & Robust QMLE & \\
\hline
\end{tabular}

Notes: Robust t-statistics (columns 1 and 2) or z-statistics (column 3) are in parentheses, below the coefficients. In column (4) $d y / d x$ is the marginal effect computed with all variables held at their mean values (QMLE coefficients). $\mathrm{R}^{2}$ is the coefficient of determination. ${ }^{* *} \mathrm{p}<0.01$, ** $\mathrm{p}<0.05,{ }^{*} \mathrm{p}<0.1$

Results for partial indexes are also very interesting. The sign of all coefficients is the same than in Table 10. Variable POP is now significant at the $10 \%$ level under $P T_{2}$ with a positive sign. Variable $P A R T$ has also become significant to explain $P T I_{1}$ : this is 
the only partial index that increases with political participation. Variables LEFT and $C O A L$ are the only variables relevant predictor for all the three partial indexes. Fiscal variables are important predictors of $P T I_{l}$ but not the rest of partial indexes, except $B A L$ in the case of $\mathrm{PTI}_{3}$. Unemployment is a significant predictor of both the first and the third partial indexes. Finally, ENPP is only relevant in the case of $P T I_{l}$. 
Table 11: Econometric estimates of equation [4]

\begin{tabular}{|c|c|c|c|}
\hline & (1) & (2) & $\begin{array}{c}(3) \\
d y / d x\end{array}$ \\
\hline Explained Variable & $P T I_{1}$ & $P T I_{1}$ & $P T I_{1}$ \\
\hline Intercept & $\begin{array}{l}-3.70 \\
(0.46)\end{array}$ & $\begin{array}{c}-0.88 * * \\
(0.034)\end{array}$ & \\
\hline$U$ & $\begin{array}{c}-0.86^{* *} \\
(2.46) \\
\end{array}$ & $\begin{array}{c}-0.05 * * * \\
(2.70) \\
\end{array}$ & -1.21 \\
\hline$B A L$ & $\begin{array}{c}0.018 * * * \\
(2.92)\end{array}$ & $\begin{array}{c}0.001 * * * \\
(3.15)\end{array}$ & 0.02 \\
\hline$E$ & $\begin{array}{c}-0.46 \\
(1.60) \\
\end{array}$ & $\begin{array}{c}-0.25^{*} \\
(1.71) \\
\end{array}$ & -0.64 \\
\hline $\bar{D}$ & $\begin{array}{c}0.007 * * \\
(2.56) \\
\end{array}$ & $\begin{array}{c}0.0004 * * * \\
(2.79)\end{array}$ & 0.010 \\
\hline$P A R T$ & $\begin{array}{l}0.20^{*} \\
(1.96)\end{array}$ & $\begin{array}{c}0.01 * * \\
(2.08)\end{array}$ & 0.27 \\
\hline$C O A L$ & $\begin{array}{l}-2.59^{*} \\
(1.82)\end{array}$ & $\begin{array}{c}-0.14 * * \\
(1.98)\end{array}$ & -3.58 \\
\hline$L E F T$ & $\begin{array}{l}2.48^{*} \\
(1.97)\end{array}$ & $\begin{array}{l}0.13 * * \\
(2.03)\end{array}$ & 3.31 \\
\hline$E N P P$ & $\begin{array}{l}2.14 * * \\
(2.05)\end{array}$ & $\begin{array}{l}0.12 * * \\
(2.29)\end{array}$ & 3.02 \\
\hline Explained variable & $\mathrm{PTI}_{2}$ & $\mathrm{PTI}_{2}$ & $\mathrm{PTI}_{2}$ \\
\hline Intercept & $\begin{array}{c}8.24 * * * \\
(7.72)\end{array}$ & $\begin{array}{c}-0.24 * * * \\
(4.20)\end{array}$ & \\
\hline$P O P$ & $\begin{array}{l}0.05^{*} \\
(1.75)\end{array}$ & $\begin{array}{c}0.003^{*} \\
(1.86) \\
\end{array}$ & 0.07 \\
\hline$C O A L$ & $\begin{array}{c}-1.79 \\
(1.51) \\
\end{array}$ & $\begin{array}{l}-0.10^{*} \\
(1.64) \\
\end{array}$ & -2.49 \\
\hline$L E F T$ & $\begin{array}{c}3.43^{* * * *} \\
(2.81)\end{array}$ & $\begin{array}{c}0.19 * * * \\
(3.00)\end{array}$ & 4.70 \\
\hline Explained Variable & $\mathrm{PTI}_{3}$ & $\mathrm{PTI}_{3}$ & $\mathrm{PTI}_{3}$ \\
\hline Intercept & $\begin{array}{c}20.85 * * * \\
(5.51)\end{array}$ & $\begin{array}{l}0.48 * * \\
(2.46)\end{array}$ & \\
\hline $\bar{U}$ & $\begin{array}{c}-0.88 * * \\
(2.23)\end{array}$ & $\begin{array}{c}-0.05 * * \\
(2.43)\end{array}$ & -1.24 \\
\hline$B A L$ & $\begin{array}{c}0.016^{* *} \\
(2.09) \\
\end{array}$ & $\begin{array}{c}0.001 * * \\
(2.34) \\
\end{array}$ & 0.022 \\
\hline$E$ & $\begin{array}{l}-0.45 \\
(1.36)\end{array}$ & $\begin{array}{c}-0.26 \\
(1.56)\end{array}$ & -0.47 \\
\hline$D$ & $\begin{array}{c}0.0003 \\
(0.08)\end{array}$ & $\begin{array}{c}0.00002 \\
(0.11)\end{array}$ & 0.0003 \\
\hline COAL & $\begin{array}{c}-1.97^{*} \\
(1.98) \\
\end{array}$ & $\begin{array}{c}-0.12 * * \\
(2.19)\end{array}$ & -2.94 \\
\hline$L E F T$ & $\begin{array}{c}3.81 * * * \\
(3.08)\end{array}$ & $\begin{array}{c}0.22 * * * * \\
(3.48)\end{array}$ & 5.24 \\
\hline $\mathrm{R}^{2}$ & 0.959 & & \\
\hline Log pseudo-likelihood & & -44.06 & \\
\hline RESET (p-value) & 0.569 & & \\
\hline Number of observations & 99 & 99 & \\
\hline Econometric Method & Clustered OLS & Clustered QMLE & \\
\hline
\end{tabular}

Notes: Robust t-statistics (column 1) or z-statistics (column 2) are in parentheses, below the coefficients. In column (3) $d y / d x$ is the marginal effect computed with all variables held at their mean values (QMLE coefficients). $\mathrm{R}^{2}$ is the coefficient of determination. ${ }^{* *} \mathrm{p}<0.01$, ** $\mathrm{p}<0.05,{ }^{*} \mathrm{p}<0.1$

Using the marginal effects computed with QMLE for the global index, we can compare the relative quantitative relevance of the most significant variables. The effect 
of LEFT is strong: leftist governments tend to enjoy transparency levels 12.46 points higher than more conservative governments. Coalition incumbents reduce its transparency by 8.75 points. The unemployment rate reduces global transparency by 2.91 points. An unitary increase in the effective number of political parties increases the global index by 6.51 , but the standard deviation of this variable is low (0.55). Finally, the marginal effect of $B A L$ is very small but the standard deviation is large (more than three times the mean). Hence, its effect is also important in some cases.

\section{Concluding Remarks}

From a methodological standpoint, our first conclusion is that relying on subjectivity-laden data from internal sources does not necessarily supposes an overoptimistic bias in transparency scores. Second, results made clear the necessity of a more in-depth examination of the survey questionnaires' dimensionality and internal consistency. Certain features of the budgetary process may be attributes of more than one latent variable, rather than reflecting only budget transparency.

Finally, while some of our empirical results on the determinants of budget transparency confirm previous findings, others point to new relationships. This is the case for the statistical significance of unemployment, the negative relationship between coalitions and transparency, and the positive impact of debt on the first partial transparency index. This last result stands in contrast to the negative effect reported by Alt, Lassen and Rose (2006) and Esteller and Polo (2008), and the negative influence of deficit on transparency. This contrast could, however, have a suitable explanation. While debt may have been accumulated during past fiscal stresses and not to be attributable to the current or previous government, deficit supposes a recent and even ongoing fiscal stress. Thus, our results may be suggesting that governments are more prone to enhance transparency when inheriting a heavy fiscal burden (high debt) and enacting sound spending policies (low deficit). 


\section{References}

Alesina, A. and Angeletos, G. M. (2005), "Corruption, Inequality and Fairness", Journal of Monetary Economics, 52(7): 1227-1244.

Alt, J. E. and Lassen, D. D. (2006), "Fiscal transparency, political parties, and debt in OECD countries", European Economic Review, 50: 1403-1439.

Alt, J. E.; Lassen, D. D. and Rose, S. (2006), "The Causes of Fiscal Transparency: Evidence from the U.S. States", IMF Staff Papers, 53: 30-57.

Alt, J. E.; Lassen, D. D. and Skilling, D. (2001), "Fiscal Transparency, Gubernatorial Popularity, and the Scale of Government: Evidence from the States", EPRU Working Paper Series, 16, Copenhagen: Economic Policy Research Unit, University of Copenhagen.

Andersen, A. L. and Nielsen, L. H. W. (2010), "Fiscal Transparency and Procyclical Fiscal Policy", EPRU Working Paper Series, 1, Copenhagen: Economic Policy Research Unit, University of Copenhagen.

Bastida, F; Benito, B. (2007), "Central government budget practices and transparency: an international comparison", Public Administration, 85 (3): 667-716.

Blöndal, J. R. (2006), "Budget Transparency: Experiences from OECD Countries", Meeting of Senior Budget Officials from Latin American Countries, Santiago de Chile, January 25.

Boyle, G. J. (1991), "Does item homogeneity indicate internal consistency or item redundancy in psychometric scales?", Personality and Individual Differences, 12 (3): 291-294.

Cattell, R. B. (1966), "The scree test for the number of factors", Multivariate Behavioral Research, 1(2): 245-276.

Colton, D. and Covert, R. W. (2007), Designing and Constructing Instruments for Social Research and Evaluation, San Francisco: Jossey-Bass.

Cortina, J. M. (1993), "What Is Coefficient Alpha? An Examination of Theory and Applications", Journal of Applied Psychology, 78(1): 98-104.

Cronbach, L. (1951), "Coefficient Alpha and the Internal Structure of Tests", Psychometrika, 16(3): 297-333.

DeCoster, J. (2004), "Data Analysis in SPSS”, (http://www.stat-help.com/spss.pdf)

De Luna, X. and Johansson, P. (2008), "Graphical diagnostics of endogeneity", in D. Millimet, J. A. Smith, and E. Vytlacil (eds.), Advances in Econometrics 21 (Modelling and evaluating treatment effects in econometrics), Amsterdam: Elsevier, 147-166. .

Esteller-Moré, A. and Polo-Otero, J. (2008), "Analysis of the causes of fiscal transparency: Evidence from Catalonian municipalities", unpublished paper.

Ferejohn, J. (1999), "Accountability and authority: toward a theory of political accountability", en A. Przeworski, S. C. Stokes and B. Manin (eds.), Democracy, accountability and representation, Cambridge: Cambridge University Press, 131-153.

Fitzpatrick, R.; Davey, C.; Buxton, M. J.; and Jones, D. R. (1998), "Evaluating patient-based outcome measures for use in clinical trials", Health Technology Assessment, 2(14): i-74.

Garson, G. D. (2008), "Scales and Standard Measures", (http://faculty.chass.ncsu.edu/garson/PA765/standard.htm).

Garson, G. $\quad$ D. (2010), "Reliability Analysis" (http://faculty.chass.ncsu.edu/garson/PA765/reliab.htm).

Hanssen, F. A. (2004), "Is There a Politically Optimal Degree of Judicial Independence?", American Economic Review, 94: 712-729. 
Heald, D. (2003), "Fiscal transparency: concepts, measurement and UK practice", Public administration, 81 (4): 723-759.

Heald, D. (2006), "Varieties of Transparency", in C. Hood y D. Heald (eds.), Transparency: The Key to Better Governance?, Oxford: Oxford University Press, 25-43.

Hood, C. (2006), "Transparency in Historical Perspective", in C. Hood and D. Heald (eds.), Transparency: The Key to Better Governance?, Oxford: Oxford University Press, 3-23.

IMF (2007a), Code of Good Practices on Fiscal Transparency (2007), Washington DC: International Monetary Fund. (http://www.imf.org/external/np/pp/2007/eng/051507c.pdf).

IMF (2007b): Manual on Fiscal Transparency (2007), Washington DC: International Monetary Fund, (http://www.imf.org/external/np/pp/2007/eng/101907m.pdf).

Jarmuzek, M. (2006), "Does fiscal transparency matter? The evidence from transition economies", (http://www.cerge.cuni.cz/pdf/gdn/RRCV_ 77 _paper_03.pdf).

Kopits, G. and Craig, J. (1998), "Transparency in Government Operations", IMF Occasional Papers, 158, Washington DC: International Monetary Fund.

Laakso, M.; and Taagepera, R. (1979), "Efective Number of Parties: A Measure with Application to Western Europe", Comparative Political Studies, 13: 3-27.

LaFaive, M. D. (2009), "MEGA, the MEDC and the Loss of Sunshine", Policy Brief, 5, Midland, Michigan: Mackinac Center for Public Policy.

Lago-Peñas, I.; and Lago-Peñas, S. (2010), "Decentralization and Electoral Accountability", Environment and Planning C: Government and Policy, 28: 318-334.

La Porte, T. M.; Demchak, C. C. and Jong, M. de (2002), "Democracy and Bureaucracy in the Age of the Web: Empirical Findings and Theoretical Speculations", Administration \& Society, 34(4): 411-446.

Lavielle, B.; Pérez, M.; and Hofbauer, H. (coords.) (2003), The Latin American Index of Budget Transparency 2003: A comparison of 10 countries, Lima, Peru: Fundar (http://www.internationalbudget.org/themes/BudTrans/English.pdf).

Likert, R. (1932), “A Technique for the Measurement of Attitudes", Archives of Psychology, 140: $1-55$.

Nunnaly, J. (1978), Psychometric theory, New York: McGraw-Hill.

OECD (Organisation for Economic Cooperation and Development) (2001), "OECD Best Practices for Budget Transparency", Paris: OECD. Available on Internet: <http://www.oecd.org/dataoecd/33/13/1905258.pdf>.

Papke, L. E.; and Wooldridge, J. M. (1996), "Econometric methods for fractional response variables with an application to 401(k) plan participation rates", Journal of Applied Econometrics, 11: 619-632.

Peixoto, T. (2010), “Transparency on the Web: a Democrat(ic) Virtue?", Personal Democracy Forum. TechPresident. (http://techpresident.com/blog-entry/transparency-webdemocrat-virtue) .

Pérez, M. (coord.) (2005), Latin American Index of Budget Transparency 2005: A comparison of 8 countries, Managua, Nicaragua: CISAS. (http://www.fundar.org.mx/indice2005/docs/Regional\%20Transparency\%20Report\%20 2005.pdf ).

Revelle, W. (2010), An introduction to psychometric theory with applications in $R$, (http://personality-project.org/r/book/). 
Rosendorff, B. P. and Vreeland, J. R. (2009), "Electoral Accountability and Data Dissemination: The Effect of Democracy on Transparency". (https://files.nyu.edu/bpr1/public/papers/BPRJRV.pdf).

Streiner, D. L.; and Norman, G. R. (1995), Health measurement scales: a practical guide to their development and use, 2nd ed., Oxford: Oxford University Press.

Vehkalahti, K.; Puntanen, S.; and Tarkkonen, L. (2006), "Estimation of reliability: a better alternative for Cronbach's alpha", Reports on Mathematics 430, Department of Mathematics and Statistics, University of Helsinki, Helsinki, Finland. (http://mathstat.helsinki.fi/reports/Preprint430.pdf).

Zinbarg, R.; Revelle, W.; Yovel, I.; and Li, W. (2005), “Cronbach's $\alpha$, Revelle's $\beta$, and McDonald's $\omega_{h}$ : Their relations with each other and two alternative conceptualizations of reliability", Psychometrika, 70(1): 123-133. 